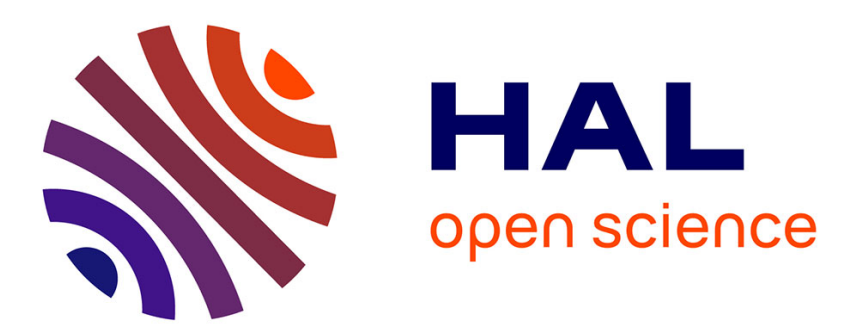

\title{
On the Duty to Implement European Framework Agreements: Lessons to be Learned from the Hairdressers Case
}

Filip Dorssemont, Klaus Lörcher, Mélanie Schmitt

\section{- To cite this version:}

Filip Dorssemont, Klaus Lörcher, Mélanie Schmitt. On the Duty to Implement European Framework Agreements: Lessons to be Learned from the Hairdressers Case. Industrial Law Journal, 2019, 48 (4), pp.571-603. 10.1093/indlaw/dwz007 . hal-02974563

\section{HAL Id: hal-02974563 https://hal.science/hal-02974563}

Submitted on 25 Oct 2021

HAL is a multi-disciplinary open access archive for the deposit and dissemination of scientific research documents, whether they are published or not. The documents may come from teaching and research institutions in France or abroad, or from public or private research centers.
L'archive ouverte pluridisciplinaire HAL, est destinée au dépôt et à la diffusion de documents scientifiques de niveau recherche, publiés ou non, émanant des établissements d'enseignement et de recherche français ou étrangers, des laboratoires publics ou privés. 
Industrial Law Journal, 2019

Acceptance Date March 20, 2019

doi:10.1093/indlaw/dwzoo7

\title{
On the Duty to Implement European Framework Agreements Concluded at European Union level
} Lessons to be Learned from the Hairdressers Case

'One cannot help wondering (even though the hypothesis seems somewhat remote) what the consequences would be, if quite apart from possibly deeming an agreement to be contrary to Community law, the Commission gave a negative assessment of the substantive choices made by the social partners'

A. Lo Faro (Regulating Social Europe, Oxford, Hart Publishing, 2000, 115).

Filip Dorssemont*, Klaus Lörcher** and Mélanie Schmitt ${ }^{* * *}$

\begin{abstract}
In this article, the authors assess the decision of the European Commission, in March 2018, not to implement a European Framework agreement concluded at sectoral level (the Hairdressers Agreement), despite a joint request to do so from the signa tory parties. They argue that the decision was not consistent with the criteria relied on by the Commission to make it. In particular, the Commission's refusal was con trary to the formal obligation enshrined in Article 155(2) Treaty on the functioning of the European Union (TFEU) to table a proposal to turn an Agreement of this kind into a Directive. Their analysis is based on, among other things, the duty to respect the autonomy of the social partners in Article 152 TFEU, and the recognition of the right to collective bargaining in Article 28 CFREU
\end{abstract}

\footnotetext{
* Professor of Labour Law, Université catholique de Louvain and Guest Lecturer, Vrije Universiteit Brussel.

** Former Legal Secretary of the Civil Service Tribunal of the European Union.

*** Senior Lecturer of Labour Law, Université de Strasbourg.
} 


\section{INTRODUCTION}

The rights of social partners in the EU legislative process have until now not come under much judicial scrutiny. The best known case concerns the General Court's (formerly called the 'Court of First Instance') so-called UEAPME judgment. ${ }^{1}$ In the UEAPME case, a decision by the European Commission (the Commission) to implement an agreement that was pro-duced following a consultation of social partners was challenged. Now, a new, still extra-judicial saga relates to a decision not to implement a truly autonomous agreement. Agreements can be construed as "autonomous" in two different ways, which are not mutually exclusive. In a first approach, the autonomous character relates to the fact that these agreements have not been implemented through a legislative or 'heteronomous' avenue, that is, by means of a Directive. In a second approach, agreements can be qualified as autonomous in so far as they have been concluded in the absence of any intention of the Commission to start the legislative procedure. In other words, in such a scenario the bargaining process has a spontaneous character. It has not been induced directly by the Commission. The word 'autonomous' is used here in its second meaning.

The Hairdressers Agreement differs substantially from that in the UEAPME case. It is a sectoral agreement covering a specific branch of industry where small and medium enterprises are dominant. Furthermore, the agreement also concerns self-employed workers. In addition, the legal and political context of the European Social Dialogue (ESD) has evolved significantly since the ruling in the UEAPME case. The year 1998 marks to some extent the end of a decade of agreements induced by the European Commission which were implemented through EU Directives. The subsequent era has been one where the social partners themselves have boosted the autonomous character of the ESD by planning work programmes defined in an autonomous way and have concluded agreements which have not been submitted for implementation. This evolution coincided with the contrasting development of the European Commission refusing to table new social policy initiatives and with the emergence of so-called better or smart regulation. ${ }^{2}$ In this respect, it is worthwhile noting that the adoption of a Recommendation on the European Pillar of Social Rights has not prompted the Commission to adopt a comprehensive social action programme, contrary to what happened when the Community Charter of the Fundamental Social Rights of Workers was proclaimed. ${ }^{3}$ The discourse of the social partners

\footnotetext{
${ }^{1}$ Case T-135/96, Union Européenne de l'artisanat et des petites et moyennes entreprises (UEAPME) $v$ Council of the European Union (CFI, 17 June 1998).

${ }^{2}$ For a critical approach on Better Regulation : L. Vogel and E. Van den Abeele, Better Regulation : A critical assessment (Brussels, ETUI, 2010). Others have argued that despite this discourse on Better Regulation, 'hard law' is coming back. See P. Pochet and C. Degryse, "The Social Agenda : is "Hard Law" Making a Come Back", in C. Degryse (ed.), Social Developments in the European Union 2008 (Brussels, ETUI, 2009), 93-111).

3 See Communication from the Commission concerning its Action Programme relating to the Implementation of the Community Charter of Basic Social Rights for Workers. COM (89) 568 final, 29 November 1989.
} 
about the autonomous character of the ESD was echoed by the Lisbon Treaty which included a reference to the autonomy of the social partners and gave a binding character to the Charter of Fundamental Rights of the European Union, which recognises, among other things, the right to bargain collectively. ${ }^{4}$ The Hairdressers Agreement constitutes an important moment within the development of the ESD. The social partners have once more proved their willingness to conclude an autonomous agreement. However, for the first time, this autonomy does not rule out the Commission promoting the bargaining process by implementing the outcome through a directive, as requested by the signatory parties. On the contrary, while the genesis of the agreement was deliberately autonomous, the intention of the social partners was to implement it via a directive.

This article addresses the legal questions stemming from this negative decision, by presenting the factual background of the conclusion of the agreement (Section 2) and describing the legal framework applicable to the ESD (Section 3) and relevant to assessing whether any obligation to implement could be claimed to exist (Section 4). The latter presupposes that the agreement is in conformity with EU Law. The 'legality test' of the substance of the agreement will be dealt with in Section 2. If the agreement fails the test, the question of whether there is an obligation to implement becomes immaterial. It will be argued that the agreement does pass the test. To examine the question of whether such an obligation to implement exists, Section 3 will focus on the two innovations introduced by the Lisbon Treaty. These two provisions (Article 152 (1) TFEU and Article 28 Charter of Fundamental Rights of the European Union (CFREU) will be considered in order to assess whether the pre-Lisbon version of Article 155 (2) TFEU entails an obligation to implement an agreement, provided that it passes the legality test and that a joint request has been filed. In search of methodological guidance, the methods of interpretation prescribed by the Vienna Convention on the Law of Treaties (VCLT) will be applied. It will be demonstrated that the various interpretation methods lead to convergent outcomes. For this reason, there is no need to apply these methods in the rigid order suggested by the Vienna Convention on the Law of Treaties. There is hence some leeway to start with an interpretation based upon the travaux préparatoires, although such an interpretation only comes into play if the general rules of interpretation provide a result which continues to be ambiguous or which is absurd or unreasonable.

The analysis of these questions is not only relevant for the conclusion of autonomous sectoral agreements. If the Commission were to refuse to implement a (sectoral) agreement which it had triggered following a formal consultation of management and labour on the possible direction of Union action in the field of social policy, our assessment would be even more critical. In such a scenario, trade unions could take advantage of the momentum to convince the employers' organisations to engage in bargaining in the shadow of the law. This

\footnotetext{
${ }^{4}$ See Art 6 TEU, Art 152 TFEU and Art 28 CFREU.
} 
hypothesis materialised after the conclusion on 21 December 2015 of an agreement entitled the 'General framework for informing and consulting civil servants and employees of central government administrations'. ${ }^{5}$ This Agreement was negotiated and entered into by the European Public Administration Employers (EUPAE) on one side and the Trade Unions' National and European Administration Delegation (TUNED), composed of the European Public Service Union (EPSU) and the European Confederation of Independent Trade Unions (CESI), on the other. The negotiations began after the Commission launched the first stage of a consultation on the consolidation of the EU Directives on the informing and consultation of workers. ${ }^{6}$ On 1 February 2016, EUPAE and TUNED made a joint request to the Commission to propose that the Agreement be implemented by a Council decision in line with Article 155(2) TFEU. However, in the Decision of 5 March 2018, the Commission refused to do so. This refusal is now being challenged before the General Court of the CJEU.?

Finally, it should be noted that the analysis would also apply if the agreements concerned were intersectoral rather than purely sectoral. The TFEU does not make any distinction between both types of agreements, to which identical treaty provisions apply.

\section{FACTUAL, POLITICAL AND LEGAL BACKGROUND}

\section{A. THE STORY OF THE HAIRDRESSERS AGREEMENT: A NEW DEVELOPMENT IN THE ESD}

On 26 April 2012, a 'European framework agreement on the protection of occupational health and safety in the hairdressing sector' ${ }^{8}$ (the 'Agreement') was concluded by the European social partners - 'Coiffure EU' representing the employers and 'UNI Europa Hair \& Beauty' as part of the trade union federation UNI Europa - in the framework of the sectoral social dialogue. It dealt with many important practical issues in the hairdressing profession. According to a Declaration published at the same time, the social partners were 'convinced of the crucial importance of preserving the good health of all persons working in the hairdressing salons'. ${ }^{9}$

\footnotetext{
${ }^{5}$ www.epsu.org/sites/default/files/article/files/EU_agreement_info_and_consul_rights_central_govern_SI GNED_EN.pdf and L. Vogel, 'The Fight to Protect Hairdressers' Health: the inside story' (2018) 17 Hesamag $12-15$.

${ }^{6} \mathrm{C}(2015) 2303$ final, 15 April 2015.

${ }^{7}$ Case T-310/18, EPSU and Willem Goudriaan v Commission.

8 http://ec.europa.eu/social/BlobServlet?docld=7697\&langld=en. See also K. Bandasz, 'A Framework Agreement in the Hairdressing Sector: The European Social Dialogue at a cross-roads' (2014) 4 Transfer 505-520.

9 'Declaration of the European Social Partners on Health and Safety in the Hairdressing Sector' 26 April 2012, http://ec.europa.eu/social/BlobServlet?docld=7698\&langld=en.
} 
In commenting positively on the conclusion of the Agreement, the Commission highlighted, among other things, that this 'agreement is a regulation by social partners for social partners and is tailor-made for small businesses, as hairdressing shops on average have less than three workers' (emphasis added). At the same time, it announced that 'before presenting a legislative proposal to the Council of Ministers, the Commission will carry out an assessment of the representative status of the signatory parties, their mandate and the legality of each clause of the agreement in relation to existing Union law. ${ }^{10}$

This assessment did not lead to a positive result. In the Refit Communication, the Commission announced it would not, during its mandate, propose legislation in the area of occupational safety and health for hairdressers, ${ }^{11}$ emphasising (at least informally) that it would not present the agreement as a proposal to the Council. While certain legal arguments were mentioned, it was obvious that the main criticism was political. This attitude was also supported by some Member States. For example, the UK government openly declared that it had influenced some other Member States to oppose what would be a very 'burdensome' directive if the Hairdressers Agreement were enacted. ${ }^{12}$ This resulted in a deadlock. ${ }^{13}$

In order to unlock this situation, the two parties to the Agreement (Coiffure EU and UNI Europa Hair \& Beauty) agreed to amend it. On 2 March 2015, a first round of negotiations between the two parties took place during which they agreed that only the core areas of the Agreement - skin protection, respiratory and musculoskeletal disorders, and workplace safety - should be part of a European directive. The remaining parts were to retain the status of a social partner agreement. On 2 March 2015 EU Vice President Valdis Dombrovskis, Commissioner Marianne Thyssen and Commission President Jean-Claude Juncker expressed support for the social dialogue in general. As regards the Hairdressers Agreement, Dombrovskis confirmed that the Commission was ready to propose it to the Council for a directive, provided that there be an impact assessment of the renegotiated agreement. ${ }^{14}$ Such a (revised) agreement was concluded on 23 June 2016. However, even this new version did not alter the position of the

\footnotetext{
10 'Hairdressing sector agrees on new measures to boost health and safety' (26 April 2012), http://ec.europa.eu/social/main.jsp?langld=en\&catld=89\&newsld=1286\&furtherNews=yes.

${ }^{11} \operatorname{COM}(2013) 685$ final.

${ }^{12}$ UK Government (Department for Work and Pensions), Appraisal of HSE's approach to negotiating and implementing European legislation (Independent Reviewer: Kim Archer, DWP; Period: January to March 2014), Annex D: UK suggestions for streamlining OSH acquis Directives, www.gov.uk/government/uploads/system/uploads/attachment_data/file/367410/hse-implementingeuropean-legislation.pdf.

${ }^{13}$ It remains to be seen whether, in the event of the Brexit, risk of such a deadlock in the future is reduced. 14 Newsletter Coiffure EU (March 2015) 4-5, www.coiffure.eu/media/blog item/20151\%20Newsletter\%20Coiffure\%20EU.pdf; see also UK Government, Health and Safety Executive Board (25 March 2015), Paper No: HSE/15/23 'The European Union level hairdressing sectoral social partners are currently amending their agreement on the protection of occupational safety and health with the intention of resubmitting it to the European Commission (EC). The EC has announced that a resubmitted agreement would be subject to an impact assessment before any decision on potentially forwarding it to the Council for a decision on implementation by a directive.'
} 
Commission, irrespective of a subsequent joint request ${ }^{15}$ by the signatory parties to implement that agreement by a Council decision into a directive. ${ }^{16}$

\section{B. CRITERIA FOR THE ASSESSMENT DEVELOPED BY THE COMMISSION}

The critical issue then is to what extent the Commission is empowered to assess the compatibility of framework agreements concluded by European social partners with EU law before deciding on their presentation to the Council as proposals for legislative acts. Before examining the applicable legal framework, it should be recalled what the Commission's (as well as at least certain Member States') intentions were regarding the original Agreement on Social Policy before it decided whether or not to propose a decision to the Council on the basis of Article 155(2) TFEU. There has been a significant shift in the approach taken by the Commission. In its first Communications, the Commission used a limited number of criteria (subsection (i) below). However, this approach was abandoned for the assessment of the Agreement, with the Commission expressing its intention to use an enlarged corpus of criteria (subsection (ii) below).

\section{i. Restricted Approach from the Commission in its Early General Communications}

In its very first Communication on the subject, ${ }^{17}$ the European Commission referred to its role as a 'guardian of the Treaties', to examine the substance of the agreements. It outlined the following elements to be examined before presenting a proposal for a decision to the Council:

39. By virtue of its role as guardian of the Treaties, the Commission will prepare proposals for decisions to the Council following consideration of the

- [1] representative status of the contracting parties, their mandate and the

- [2] 'legality' of each clause in the collective agreement in relation to Community law, and the

- [3] provisions regarding small and medium-sized undertakings set out in Article 2(2).

Nothing in this Communication justifies the idea that the Commission could carry out a test of the appropriateness of the substance of an agreement. A guardian of Treaties should indeed carry out a test of legality ('test de légalité' as opposed to a 'test d'opportunité'). The overall approach is a test on the representative status of the signatory parties and on the 'legality' of each clause, according to the Commission, including the issue of the 'burdensome' character of small and medium-sized enterprises (SMEs), to which the Agreement on Social Policy (ASP, now part of the Social Policy Title) refers to as a restriction on EU law-making powers under Article 153(2)(b) TFEU.

\footnotetext{
${ }^{15}$ www.uni-europa.org/wp-content/uploads/2016/11/20161121-Joint-ETUC-UNI-Europa-Coiffure-EU-Letter-toEC.docx.pdf.

${ }^{16}$ www.uni-europa.org/wp-content/uploads/2016/06/EFA_OHS_HairdressingSector_signed_20160623.pdf.

${ }_{17}$ Communication concerning the application of the Agreement on social policy presented by the Commission to the Council and to the European Parliament (COM (93) 600 final).
} 
In the next Communication, ${ }^{18}$ the only test described relates to the 'representative status' or to the issue of 'appropriate representation'. The same approach was repeated in 1998 and 2002 in further Communications. ${ }^{19}$ However, in the former of these, the Commission does make a distinction between induced and spontaneous bargaining. ${ }^{20}$ According to the Commission, in the case of spontaneous bargaining, a more elaborate appropriateness test would be warranted; in the case of an induced agreement, the fact that the Commission did envisage a proposal seems to indicate that it had already carried out such a test. This is exactly the scenario of the Hairdressers case.

\section{ii. A Broad Approach to the Agreement Subsequently}

Concerning the assessment criteria for the content of the Agreement, an important shift in the Commission's attitude can be noted. At first, the Commission favoured a more limited approach and did not refer to the assessment of appropriateness.

However, in a letter written by the then responsible Commissioner Andor in $2013,{ }^{21}$ the criteria were enlarged. Going far beyond the usual criteria for examinations by the Commission under Article 155 TFEU ([1] to [3]), particular elements of the 'Smart Regulation' Agenda ([4]) and general 'appropriateness' issues ([5]) were now also included. Criteria referred to:

- $\quad[1]$ the representativeness of the signatory parties,

- $\quad$ [2] the legality of the clauses in the agreement in relation to EU law,

- [3] the relevance of the provisions regarding SMEs,

- [4] the cost and benefit of the measures contemplated, and the

- [5] appropriateness of EU action in this field.

This shift is due to a development in the efforts to improve the EU leg-islative process. Starting with 'Better regulation' via 'Smart regulation', the Commission's present political approach is defined in its recent Refit communication. ${ }^{22}$ By going beyond this well-established scheme the European Commission clearly takes the view that it has a right to assess the appropriateness of the Agreement with regard to its substance. In particular, it gives rise to an overall test of appropriateness on any proposed or adopted instrument based upon a policy to establish a 'simple, clear, stable and predictable regulatory framework for businesses, workers and citizens', reviewing the entire stock of EU legislation, 'to identify burdens, inconsistencies, gaps or ineffective measures and to make the necessary proposals to follow up on the findings of the review'. The Commission does not at all differentiate between the two modes of implementation.

\footnotetext{
${ }^{18} \operatorname{COM}(96) 448$ final.

${ }^{19} \operatorname{COM}(98) 322$ final and in COM (2002) 341 final.

${ }^{20} \mathrm{COM}(98) 322$ final, point 5.4.2, p. 19.

${ }^{21}$ Letter dated 30 January 2013.

${ }^{22}$ COM (2013) 685 final. See comments by I. Schömann, «Mieux légiférer dans I'Union Européenne : simplifier ou dénaturer l'acquis communautaire? Analyse critique d'une initiative de la Commission au regard du droit du travail » (2016) I Revue de droit comparé du travail et de la sécurite sociale 6-15; id., 'EU REFIT Machinery "Cutting Red Tape" at the Cost of the Acquis Communautaire' (Brussels: European Trade Union Institute, Policy Brief 2015.5).
} 
Furthermore, the criteria for carrying out this review go beyond an even broadly interpreted legality test. This approach was confirmed in the recent Commission Recommendation of 26 April 2017. In this document the Commission states that 'agreements concluded between the social partners shall be implemented at the level of the Union and its Member States, where appropriate' (emphasis added). ${ }^{23}$

This new approach led the Commission to indicate in this Communication that it would not table a legislative proposal to implement the framework agreement during its present mandate. However, no attempt is made in this Communication to justify the decision not to table a proposal during its present mandate. The ETUC had already criticised this attitude in 2013:

By refusing to present the [Agreement] to the Council, the Commission is not fulfilling its function as the guardian of the treaties. It should promote the role of the social partners and respect their autonomy. ${ }^{24}$

In 2016 the Commission indicated that it was still in the process of assessment (obviously the appropriateness and 'EU added-value character' of the Agreement) while not refusing in a formal way to table such a proposal. ${ }^{25}$ However, it has still failed to do so.

\section{LEGAL ASSESSMENT}

\section{i. Relation to EU Law}

Some concern has been expressed about the relation of the Agreement (in particular its provisions) to EU law, particularly as regards legal uncertainty. It has been argued that EU standard-setting should not allow for different standards for each branch. Neither argument is convincing as will be demonstrated subsequently.

Part 3 of the Agreement highlights its relationship with EU law ${ }^{26}$ and the fact that it is in line with the general principles of EU labour law and in particular with the principles concerning safety and health. The former is expressed in Article 153(2)(b) TFEU ('minimum requirements'), leaving space for further improvements. The latter is additionally expressed by the unique definition of the legal basis in Article 153(1)(a). Finally, in many respects the Agreement refers, through more specific definitions, to EU (safety and health) law.

The second criticism, concerning the general approach of highlighting one sector and thus departing from the 'system of safety and health' that it would require, is

\footnotetext{
${ }^{23}$ Commission Recommendation of 26 April 2017, C (2017) 2600 final.

${ }^{24}$ ETUC resolution 'Stop the deregulation of Europe: Rethink Refit' (Adopted at the meeting of the Executive Committee on 3-4 December 2013), www.etuc.org/sites/www.etuc.org/files/EN-ETUCresolution-stop-the-deregulation-of-Europe-Rethink-Refit.pdf.

${ }^{25}$ Hairdressing Social Partner Agreement: State of Play, 12 December 2016 ('the Commission replied already evasively to the joint request'); www.uni-europa.org/2016/12/12/hairdressing-social-partneragreement-state-play.

${ }^{26}$ ('without prejudice' to any more favourable EU standard), see also other Framework Agreements containing equivalent 'most favourable' clauses without having been challenged Directive 2010/18/EU (Clause 8), Directive 97/81/EC (Clause 6), Directive 1999/70/EC (Clause 8).
} 
not convincing for several reasons. First, it is not a 'legal' argument as such but more related to appropriateness considerations. There is no (express) legal requirement to follow the same approach for all sectors. Even assuming, however, that it could nevertheless be considered a 'legal' argument, Article 16 of the Framework Directive $(8 / 391 / \mathrm{EEC})$ paves the way for individual directives. Moreover, the sectoral social dialogue is precisely aimed at adapted solutions to specific sectors and thus has produced a number of specific agreements which have already been implemented by the Council without being challenged for 'inconsistency' with a general 'systematic' approach. And this is also true for specific elements in the 'safety and health' area, like working time in specific sectors (civil aviation ${ }^{27}$, seafarers ${ }^{28}$ ) and even concerning specific risks, appearing for example in the maritime ${ }^{29}$ and hospital sectors ${ }^{30}$. Finally, EU legislation expressly recognises specific dangers of cosmetic products. ${ }^{31}$

\section{ii. Substantive issues}

The most developed argument against the legality of the transposing an agreement into a a directive is the lack of a legal basis in Article 153(1) TFEU. Article 155(2)(1) TFEU explicitly refers to 'matters covered by Article 153' TFEU. Article 153(1)(a) TFEU relates to 'workers' and does not mention 'self-employed' persons who are also addressed in the Agreement. However, it appears very clear that 'bogus self-employed' persons are covered by the notion of 'worker', as elucidated in the Allonby judgment of the CJEU. ${ }^{32}$ Moreover, the 'self-employed' have been included in the protection of safety and health secondary legislation. The eighth health and safety Directive ${ }^{33}$ has several features in relation to 'selfemployed persons', including referring to them in the recitals, defining them in Article 2(d), including them in the safety and health system in Article 6(b) and (d) and finally requiring employers to cooperate with them according to Article 8(i). A similar problem has arisen in relation to health and safety in the construction sector. Indeed, its recitals ${ }^{34}$ refer to the self-employed.

Analysing this approach, one could argue that the 'self-employed' are not to be protected as such, but are rather (more indirectly) to be involved in the management of safety and health at the workplace. The idea behind such a limited approach might be that they are not treated as workers but more as if they were 'additional' employers. However,, these references could be considered rather unconvincing, considering that Article 153(1)(a) TFEU also refers to self-employed persons. Nevertheless, there is an important element in Article 153(1)(a) TFEU which is different from the other provisions mentioned

\footnotetext{
${ }^{27}$ Directive 2000/79/EC.

${ }^{28}$ Directive 1999/63/EC.

${ }^{29}$ Directive 2009/13/EC.

${ }^{30}$ Directive 2010/32/EU.

${ }^{31}$ See for more details: https://ec.europa.eu/growth/sectors/cosmetics/legislation_en.

${ }^{32}$ CJEU Judgment 13 January 2004 - Case C-256/01 - Allonby - Reports 2004 I-873, para. 71.

${ }^{33}$ Directive $92 / 57 / E E C$.

${ }^{34}$ Directive 2001/45/EC.
} 
above, in that the wording is more open: 'improvement in particular of the working environment to protect workers' health and safety'. Although it mentions 'workers' health and safety' and could therefore be considered as limited to 'workers', the words 'in particular' are based on a wider concept of 'working environment'. Moreover, it is stressed that it the content of the standard has to be improved. It is very rare that the TFEU, in providing for a legal basis for legislation, not only describes the scope but also includes a specific aim ('improvement').

Additionally, it would appear important to analyse this competence question in relation to the substantive need for the 'self-employed' to be covered by safety and health regulations. First, the fifth recital of the TEU and - even more specifically in relation to social policy - Article 151(1) TFEU refer to the European Social Charter (ESC). A similar reference is also included in paragraph 5 of the legally binding (Article 6(1) TEU ) Charter of Fundamental Rights of the European Union (CFREU) and - even more specifically in relation to safety and health at the workplace - in the Explanations on Article 31(1) CFREU. ${ }^{35}$ On this basis the (definitive) interpretation of Article 3 ESC by the European Committee of Social Rights considered that

the situation ... is not in conformity with Article $3 \S 1$ of the Charter on the ground that certain categories of self-employed workers are not sufficiently covered by the occupational health and safety regulations. ${ }^{36}$

Looking more specifically at the Agreement and in particular at the general introduction in the first sentence ('exclusion would have negative effects for overall EU social policy objectives as described in Article 151 of the Treaty'), the exclusion of the self-employed from safety and health protection would have negative effects for the overall EU social policy objectives because it would violate the 'fundamental social rights such as those set out in the European Social Charter' that form their basis (see above). Additionally, it can be argued that this approach is further expressed in the General Considerations and in in Part I Clause 2(2) of the Agreement by the reference to work in a hairdressing salon (and not only to the work of the self-employed).

In conclusion, the inclusion of the self-employed in (parts of) the protection provided for in this Agreement does not exceed the competence provided for in Article 153(1)(a) TFEU.

A further criticism could be raised in relation to the insufficient consideration of the position and interests of SMEs. Even assuming that this would have to be considered a legal argument by referring to Article 153(2)(b) TFEU, at least in this specific case it is not relevant. The Agreement was concluded by an employers' organisation representing nearly only SMEs (or even only 'micro-

\footnotetext{
35 'Paragraph 1 of this Article is based on Directive 89/391/EEC on the introduction of measures to encourage improvements in the safety and health of workers at work. It also draws on Article 3 of the Social Charter...' OJ C 303/17 - 14.12.2007

${ }^{36}$ European Committee of Social Rights, Conclusions XX-2 (January 2014).
} 
enterprises' with fewer than 10 persons employed ${ }^{37}$ ). It is not conceivable that the Commission could have better assessed this requirement in any respect. Therefore, in substance, this criterion poses no problem in this case. Moreover, the content of the Agreement shows that the interests of SMEs have been taken into account. Indeed, by referring to (the necessity of) mutual trust, which can normally only be developed on a personal basis in SMEs, if not only in microenterprises, paragraph (4) of the General Considerations acknowledges this as a 'productive factor'. Last but not least, it should be noted that the European Committee of Social Rights has stressed in its Conclusions XX-2 (2013) the importance of safety and health protection (by labour inspection) in SMEs. ${ }^{38}$ Taking into account the relevance of (Article 3 of) the ESC, this step to address specifically the SMEs is an additional argument for effectively protecting the safety and health of workers in these enterprises (and not to reduce them). In conclusion, this criterion is not applicable in the present case. But even if it were to be applied it is clear from its content that it is respected.

\section{THE CONSTITUTIONAL FRAMEWORK: IN PARTICULAR, THE PRINCIPLE OF COLLECTIVE AUTONOMY AND THE RIGHT TO BARGAIN COLLECTIVELY}

The issue of whether the Commission has an obligation to table a legislative proposal at the request of the signatory social partners of the Agreement essentially needs to be construed on the basis of Article 155 TFEU. This Article needs to be interpreted in conjunction with Article 152(1) TFEU and in consideration of Article 28 CFREU. Since the entry into force of the Lisbon Treaty, both of the latter grounds are legally binding as parts of EU primary law. Moreover, both the wording and the philosophy of Article 152(1) TFEU and Article 28 CFREU contribute to strengthening the legal force of European sectoral agreements concluded on the basis of Article 155 TFEU as well as the authority of social partners.

Our analysis is based on the legal implications stemming from the core concept of the 'autonomy' of social partners, as enshrined in Article 152(1) TFEU. It first derives from this provision the Commission's obligation to respect the social partners' exercise of their autonomy, especially when they have reached an agreement for which they ask for an implementation by directive (2.1). This concept also supposes a renewed analysis of the right to bargain collectively, protected by Article 28 CFREU which is in line with other international human rights instruments (2.2).

\footnotetext{
${ }^{37}$ See Article 2(3) of the Annex of Commission Recommendation of 6 May 2003 concerning the definition of micro, small and medium-sized enterprises (OJ L 124, 20/05/2003 p. 36-41).

${ }^{38}$ European Committee of Social Rights, Conclusions XX-2 (January 2014) - General Introduction, p. 6, see also the introduction in the 'Statement of interpretation on Article 3 ' (p. 5).
} 


\section{A. ARTICLE 152(1) TFEU AND THE DUTY TO RESPECT THE AUTONOMY OF SOCIAL PARTNERS}

Since the entry into force of the Lisbon Treaty, the European Union 'recognises and promotes the role of the social partners at its level, taking into account the diversity of national systems. It shall facilitate dialogue between the social partners, respecting their autonomy' (Article 152(1) TFEU). This provision is applicable to the Union and then via Article 13 TEU to all European institutions, as opposed to Article 154 TFEU which is only binding for the Commission. Contrary to Article 154 TFEU, this obligation makes a reference to the concept of 'autonomy', albeit without providing any definition.

The notion of autonomy has rightly been defined by the $\mathrm{CJEU}^{39}$ as the right of self-government. In the French language version, the CJEU states more accurately from an etymological point of view and more elaborately that autonomy means 'le droit de se gouverner par ses propres lois' (free translation: "the right of the parties to regulate their own affairs through rules they themselves make"). Though the application of this notion can differ from one case to another, the definition given by the CJEU has a generic scope.

Applied to the field of collective bargaining, it could be argued that the EU institutions respect collective autonomy, that is, the capacity of social partners to adopt laws applicable to the employment relations concerned. The latter are the employment relations linked to their sectoral representa-tive status. Since 2002, the Commission itself states that 'the Treaty [Article 155(1)] also recognises the social partners' ability to undertake genuine independent social dialogue, that is to negotiate independently agreements which become law'. ${ }^{40}$ The Commission uses the notion of 'autonomous dialogue' in order to highlight the 'voluntaristic' nature of the process as opposed to the consultation process in Article 154.

The notion of collective autonomy can thus be understood as entail-ing an obligation for public authorities to refrain from intervention. ${ }^{41}$ The position of the former Court of first instance in UEAPME, which dealt with an agreement negotiated and concluded after the consultation of social partners by the Commission, is in line with this negative dimension of collective autonomy. The Court ruled that 'it is the representatives of management and labour concerned, and not the Commission, which have charge of the negotiation stage properly so

\footnotetext{
${ }^{39}$ CJEU, 29 July 2010, C-151/09, Federación de Servicios Públicos de la UGT (UGT-FSP) v Ayuntamiento de La Línea de la Concepción, María del Rosario Vecino Uribe and Ministerio Fiscal, § 42 : 'Next, it must be observed that the word 'autonomy', according to its usual meaning in everyday language, describes the right of self-government'. Unfortunately, the CJEU does not tend to refer to the notion of collective autonomy. In many cases, it has not referred to such a notion with regard to the legal construction of EU law. In CJEU, 15 July 2008, Case C-271/08, Commission v. Germany, the use of collective autonomy only refers to the German Basic Law.

40 Communication from the Commission of 26 June 2002, The European social dialogue, a force for innovation and change, $\operatorname{COM}(2002) 341$ final, paragraph 1.

${ }^{41}$ In a similar vein, see the use of autonomy as 'collective laissez faire' in the contribution of A. Bogg and $\mathrm{R}$ Dukes, 'The European Social Dialogue: from autonomy to here' in N. Contouris and M. Freedland (eds), Resocialising Europe (Cambridge, CUP, 2013) 479-484.
} 
called'42. It thus follows that '(the) negotiation stage, which may come into being during the consultation stage initiated by the Commission, depends exclusively on the initiative of those representatives of management and labour who wish to launch such negotiations'. ${ }^{43}$

This negative dimension of the concept of autonomy should however be complemented by a positive dimension that public authorities are obliged to ensure and promote ${ }^{44}$. Article 152(1) TFEU constitutes a significant new element in favour of this second interpretation. It is clear that its provisions do not put an emphasis on the issue of 'respect' in the sense of refraining from intervention. In fact, Article 152(1) TFEU stresses an obligation to recognise and to promote social dialogue.

Furthermore, having a general scope, Article 152(1) TFEU complements Article 154(1) TFEU which is more focused on the consultation procedure and the bargaining process as opposed to its outcome and implementation. Article 152(1) TFEU is applicable to all stages of the collective bargaining process, from the very first discussions about possible future negotiations until the agreement's implementation phase. The most coherent interpretation of the obligation to respect autonomy in its positive or 'proactive' dimension is that the Commission should support the process by tabling the legislative proposal which guarantees that agreements are received within the EU legal order.

This interpretation is consistent with the so-called principle of 'horizontal subsidiarity' or 'social subsidiarity' as developed by Bercusson ${ }^{45}$ and which is implicitly enshrined in Article 152(1) TFEU. This principle consists of two parts. On the one hand, it implies that social partners have priority to act freely in governing their own affairs, as permitted by the abstention of public authorities. According to the Commission itself, the principle of horizontal subsidiarity firstly allows the possible exclusion of the Commission by the social partners from the consultation process. ${ }^{46}$ On the other hand, the Commission must intervene in a subsidiary and graduated way so as to support, complement and even replace collective autonomy where it may fail. The idea of social subsidiarity explicitly underlined by the Commission is limited to this latter form of intervention. In 2002, the Commission indeed stated that 'the outcome may be independent social dialogue, multi-sectoral or sectoral, and ultimately, therefore, agreements

\footnotetext{
${ }^{42}$ Case T-135/96, 17 June 1998, ECLI:EU:T:1998:128, para. 78.

${ }^{43}$ Case T-135/96, 17 June 1998, ECLI:EU:T:1998:128, para. 75.

${ }^{44}$ See M. Schmitt, Autonomie collective des partenaires sociaux et principe de subsidiarité dans l'ordre juridique communautaire (Presses Universitaires d'Aix-Marseille, 2009) 670 pages. In the same vein, Bogg and Dukes also state that collective laissez faire is not sufficient and that 'a strong and committed political support is needed from the institutions'. Though the authors have argued and exemplified this in respect of the genesis of agreements, in our view this is also valid for the subsequent stage of the implementation. In a similar vein, see the use of autonomy as 'collective laissez faire' in the contribution of A. Bogg and R Dukes, 'The European Social Dialogue: from autonomy to here' in N. Contouris and M. Freedland (eds), Resocialising Europe (Cambridge, CUP, 2013) 484.

45 B. Bercusson, 'Maastricht: a fundamental change in European labour law' (1992) Industrial Relations Journal 23, 177; 'The Dynamic of European Labour Law after Maastricht' (1994) 23 ILJ 1.

${ }^{46}$ Communication from the Commission of 26 June 2002, COM(2002) 341 final, paragraph 1.1.
} 
which may subsequently be incorporated into Community law. This is a practical application of the principle of social subsidiarity. It is for the social players to make the first move to arrive at appropriate solutions coming within their area of responsibility; the Community institutions intervene, at the Commission's initiative, only where negotiations fail'. ${ }^{47}$ [Emphasis added.]

In our view, based on Article 155 TFEU, read in conjunction with Article 154(1) and Article 152(1) TFEU, for the EU institutions, supporting collective autonomy means providing social partners with all means which are necessary for the exercise and the effectiveness of their autonomy. Should these 'first stage' interventions not be sufficient for the achievement of these aims, EU institutions shall then reinforce their interventions by acts or actions complementing (and not immediately replacing) those of the social partners. This is precisely the meaning of implementation of agreements by a directive as laid down by Article 155(2) TFEU: this process tends to ensure the (broadest) effectiveness of the agreement when social partners themselves are unable to do so. As was ruled in UEAPME, ' $(\mathrm{t}$ )he participation of the two institutions in question [Commission and Council] has the effect [...] of endowing an agreement concluded between management and labour with a Community foundation of a legislative character'. ${ }^{48}$

In sum, Article 152(1) TFEU obliges the Commission to try to bring about the translation of the regulations stemming from the exercise of collective autonomy into the realm of the EU legal order. Autonomy is essentially about the relation between legal orders, as highlighted by Santi Romano in his seminal Ordinamento giuridico. ${ }^{49}$ This means that collective autonomy as a legal order is not tantamount to independence or self-sufficiency vis-à-vis the EU legal order. The most significant element of the relationship between both legal orders is precisely the implementation process set out in Article 155(2) TFEU ${ }^{50}$. Consequently, the idea that the Commission would not be obliged to propose an implementation directive is at odds with such an approach to collective autonomy. Furthermore, an intervention cannot be considered as a violation of the negative dimension of autonomy, insofar as it is being explicitly requested by the signatory parties concerned.

\footnotetext{
47 Ibid.

${ }^{48}$ Case T-135/96, 17 June 1998, ECLI:EU:T:1998:128, para. 88.

${ }^{49}$ Santi Romano, L'ordinamento giuridico, 2nd edn (Florence Sansoni, 1946).

${ }^{50}$ This idea of collective autonomy also corresponds to the concept of 'autonomy of the parties' used by EU secondary legislation. See Directive 94/45/EC of 22 September 1994 on the establishment of a European Works Council or a procedure in Community-scale undertakings and Community-scale groups of undertakings for the purposes of informing and consulting employees, OJ L 254 , 30/09/1994 p. 64, Recital No. 15: 'Whereas, in accordance with the principle of autonomy of the parties, it is for the representatives of employees and the management of the undertaking or the group's controlling undertaking to determine by agreement the nature, composition, the function, mode of operation, procedures and financial resources of European Works Councils or other information and consultation procedures so as to suit their own particular circumstances' (emphasis added). It is only where no agreement has been reached or by the common will of both parties that 'subsidiary requirements' as implemented in national legislation apply.
} 
Last but not least, the idea that the recognition of 'autonomy' requires public authorities not just to respect but also to promote it is consistent with the recognition of the freedom of collective bargaining in Article 28 CFREU. Despite the approach of describing collective bargaining as a 'freedom', hence a 'right of collective bargaining', Article 51(1) CFREU, which has a transversal scope, indicates that the rights under the Charter need to be not only respected but also promoted, as a 'right to' would imply.

\section{B. ARTICLE 28 CFREU AND THE COMPREHENSIVE INTERPRETATION OF THE RIGHT TO COLLECTIVE BARGAINING}

Since 2000, a right to collective bargaining has been set out in Article 28 CFREU. The incorporation of this provision into the EU Charter constitutes an important change, since the CJEU initially ${ }^{51}$ refused to recognise the existence of a fundamental right to bargain collectively in EU law, though it was expressly recognised in the European Social Charter of the Council of Europe (Article 6(2)).

According to recent CJEU case law, Article 28 CFREU, alongside other European instruments, recognises the fundamental nature of the right to bargain collectivel $y^{52}$. The CJEU, as all other EU institutions, must therefore protect and promote this right. It derives from Article 28 CFREU, supported by the general provisions of the EU Charter, that within the EU legal order, the right to bargain collectively at sectoral level may receive a comprehensive interpretation. Moreover, the right to bargain collectively entails the right of the parties to autonomy, which can thus be considered as "inherent in that right ${ }^{53}$. Imposing the same notion, ILO standards and, maybe to a lesser extent, ECtHR case law should be interpreted and applied in a 'synergetic' way.

The right to negotiate and conclude a European sectoral agreement is clearly protected by Article 28 CFREU. According to the Explanations relating to Article 28 CFREU, which refer to the clarification concerning Article 27 CFREU (workers' right to information and consultation within the undertaking), '( $\mathrm{t}$ )he reference to appropriate levels refers to the levels laid down by Union law or by national laws and practices, which might include the European level when Union legislation so provides'. There is no doubt then that the process of European sectoral level dialogue is underpinned by by primary law provisions recognising the role of social dialogue and social partners' autonomy.

According to Article 152 (1) TFEU, the EU must recognise and promote the role of the social partners, including the European sectoral social partners, at

\footnotetext{
${ }^{51}$ See Case C-67/96 Albany [1999] ECR I-5751 and especially the Opinion of Advocate General Jacobs, para. 146.

${ }^{52}$ Case C-271/08, Commission v Germany [2010], para. 38. The other instruments quoted by the CJEU in para. 37 are the following: Article 6 of the European Social Charter and Article 12 of the Community Charter of the Fundamental Social Rights of Workers of 9 December 1989. It has to be noted that ILO Convention No 98 is not mentioned.

53 Opinion of Advocate General Trstenjak delivered on 14 April 2010 in Case C-271/08, Commission v Germany, paras 78 and 80.
} 
Union level. This interpretation is even clearly supported by the Commission: 'The new article 152 of the Treaty on the Functioning of the European Union (TFEU) highlights the Union's commitment to promoting the role of European social partners and supporting social dialogue. It also acknowledges the autonomy of European social partners. In addition to cross-industry social dialogue, sectoral social dialogue is an increasing part of this European governance tool'. ${ }^{54}$ [Emphasis added.]

Along the same lines, Article 155(1) and (2) TFEU protects the right of social partners to dialogue which 'may lead to contractual relations, including agreements' concluded at the Union level. Collective bargaining at sector level, be it conducted following a consultation with the Commission under Article 154 TFEU or on an autonomous basis by social partners, falls under Article 155 provisions.

Moreover, a parallel can be drawn with the scope of the right to collective action, which is also protected by Article 28 CFREU. The CJEU applied Article 28 CFREU to a circular that an international federation sent to its affiliates. ${ }^{55} \mathrm{It}$ should be noted that such an interpretation is not imposed by the Explanations to Article 28 CFREU, according to which the question of whether the right of collective action may be carried out in parallel in several Member States comes under national laws and practices. This interpretation more generally strengthens the argument that the transnational or supranational scope of the fundamental right to bargain collectively is recognised in the EU legal system. This interpretation is also consistent with Article 152(1) TFEU, as well as the objective of social dialogue laid down in Article 151 TFEU.

Article 28 CRFEU should also be interpreted in the light of other European and international instruments protecting the right to collective bargaining. This approach is not only theoretically relevant as a way to ensure coherence between the legal texts of different normative systems. It is also laid down in general provisions of the EU Charter (cf. Articles 52(2) and 53 CFREU) which require coherent and harmonious interaction between European and international instruments. Moreover, the General Court has already applied this methodology for the interpretation of Article 28 CFREU in Heath $v$ ECB. The Appeal Chamber of the General Court in that judgment of 18 June $2013^{56}$ stated that 'by virtue of Article 52, paragraph 3, of the Charter of Fundamental Rights, the meaning and scope of article 28 are considered to be the same as those laid down by Article 11 ECHR'. However, by refusing to recognise an obligation to establish a collective bargaining procedure in this particular case, the General Court ignored the ECtHR 'doctrine' of positive obligations incumbent on the Member States in order 'to secure the enjoyment of the rights under Article 11 of

\footnotetext{
${ }^{54}$ See Commission Staff Working Document on the functioning and potential of European sectoral social dialogue, Brussels, 22 July 2010, SEC(2010) 964 final, esp. '3.2 Negotiations and capacity to negotiate agreements' (p. $12 \mathrm{ff})$.

55 See Case C-438/05, Viking [2007], ECR I-10779.

${ }^{56}$ G.C., 18 June 2013, case T-645/11 P, Heath, $\$ 155$ (available only in French).
} 
the Convention'57. For the Strasbourg Court, this doctrine implies the establishment of a procedure permitting the exercise of the right to collective bargaining, without which the very existence of the right is affected. The further correlation between Article 12 CFREU and Article $11 \mathrm{ECHR}$, which is required from a basic textual viewpoint, may strengthen the protection of the right to collective bargaining. Article 12 CFREU does not make the exercise of the freedom of association subject to compliance with EU law (unlike Article 28 CFREU), so that the only limitations that can be applied are those laid down in the general provisions of the Charter (Article 52 (1)). Despite these shortcomings with respect to ECtHR case law and to the EU Charter itself, this decision represents an important first step toward the full recognition of the right to collective bargaining in the EU legal order. ${ }^{58 .}$

Among international law instruments, ILO standards are obviously relevant. According to its preamble, the EU Charter 'reaffirms [...] the rights as they result, in particular, from [...] international obligations common to the Member States'. This synergetic perspective is required by the (Revised) European Social Charter of the Council of Europe, which is specifically referred to in the fifth recital of the TEU as well as in Article 151(1) TFEU and whose Article 6(2) protecting the right to collective bargaining is mainly based on ILO Convention No. 98 on the 'Right to Organize and Collective Bargaining' (1949). In the same vein, the ECtHR developed in its important Demir and Baykara judgment a method based on the systematic reference to relevant European and international instruments for the interpretation of Convention rights. ${ }^{59}$

ILO standards laid down in ILO Convention No. 98 should therefore guide the interpretation of Article 28 CFREU. This convention explicitly enshrines the two dimensions of collective autonomy: 'Under the terms of Article 4 of the Convention, collective bargaining must be free and voluntary and respect the principle of the autonomy of the parties. However, the public authorities are under the obligation to ensure its promotion'. ${ }^{60}$ The terms used by Article 4 of Convention No. 98 are crystal clear: 'where necessary', namely in case of failure of (totally) voluntary negotiation, State parties shall take 'measures [...] to encourage and promote the full development and utilisation of machinery for voluntary negotiation between employers or employers' organisations and

\footnotetext{
${ }^{57}$ ECtHR, 2 July 2002, Wilson, National Union of journalists and others v. The United Kingdom, No. 30668/96, $30671 / 96$ and $30678 / 96, \S 48$.

${ }^{8}$ On the issue of relations between Article 28 CFREU and Article 6 of the (Revised) European Social Charter, see F. Dorssemont, 'A Matrix for Industrial Relations. The Right to Bargain Collectively Article 6' in N. Bruun, K. Lörcher, I. Schömann, S. Clauwaert (eds.), The European Social Charter and the Employment Relation (Oxford, Hart, 2017).

${ }^{59}$ See K. Lörcher, 'The New Social Dimension in the Jurisprudence of the European Court of Human Rights (ECtHR): The Demir and Baykara Judgment, its Methodology and Follow-up' in F. Dorssemont, K. Lörcher and I. Schömann (eds.), The European Convention on Human Rights and the Employment relation (Oxford, Hart, 2013), 3-46.

${ }^{60}$ ILO, General Survey, Committee of Experts on the Application of Conventions and Recommendations, International Labour Conference 2012, Report III Part 1 B, § 200.
} 
workers' organisations, with a view to the regulation of terms and conditions of employment by means of collective agreements'.

\section{A POSITIVE OBLIGATION FOR THE COMMISSION TO SUBMIT A PROPOSAL UNDER ARTICLE 155(2) TFEU}

\section{A. THE LEGAL FRAMEWORK FOR THE DUTY TO IMPLEMENT SOCIAL PARTNERS' AGREEMENTS AT EU LEVEL}

Article 155(2) TFEU states in anunambiguous way that

agreements concluded at Union level shall be implemented either in accordance with the procedures and practices specific to management and labour and the Member States or, in matters covered by Article 153, at the joint request of the signatory parties, by a Council decision on a proposal from the Commission. [Emphases added.]

Since it cannot be disputed that the Hairdressers Agreement does consti-tute an agreement (between management and labour), dealing with a mat-ter covered by Article 153 TFEU, and that a joint request of the signatory parties has been made, the question arises whether this provision entails an obligation for the Commission to make a proposal to the Council to implement it. In this paragraph, this question will be analysed on the basis of a teleological and contextual (systematic) method of interpretation. This approach is undertaken in order to gain a better understanding of the 'contemporary' lexical meaning of the text, which was preceded by previous and rather distinct formulas proposed by the 'social partners'. The lexical interpretation of the provision will therefore be made prior to any teleological or contextual interpretation. It is well known that the CJEU tends to interpret EU law in a teleological and contextual way; it does not interpret a provision in an isolated manner but tries to interpret it in a systematic way. The system concerned is the TFEU. As shown above, some of the constitutional provisions which are part of this system are postdate the adoption of Article 155 TFEU.

We argue that there is an obligation for the Commission to submit a proposal if a joint request was made by the signatory parties. Such a thesis does not reflect a communis opinio within the legal doctrine. However, several of the authors who have considered this issue were not able to take account of some of the new Treaty provisions. The fact that some colleagues take a divergent view from ours therefore does not mean that they did not properly apply the systematic or teleological method of interpretation. Many colleagues defended the thesis of a positive obligation incumbent on the Commission prior to the adoption of the Lisbon Treaty. One of the most passionate advocates of the thesis of a positive obligation was Brian Bercusson ${ }^{61}$, according to whom the

\footnotetext{
${ }^{61}$ B. Bercusson, 'Maastricht: a fundamental change in European labour law' (1992) Industrial Relations Journal 177, specifically 187-188; B. Bercusson, 'The Dynamic of European Labour Law after Maastricht' (1994) 23 ILJ 1, specifically 27-28. For a summary of the discussions, see B. Bercusson, European Labour Law (London: Butterwords, 1996, 539. See also notes 62, 76 and 80.
} 
Commission must be refused the right to reject: 'The Commission has no discretion; if there is a joint request by the signatory parties, the Commission must propose it. But the right to reject is not given to the Commission' ${ }^{62}$. The Commission still plays an important role, as it can guide the social partners during negotiations and point out aspects allowing the agreement to be approved by the Council, at least insofar as the collective bargaining was induced. It is clear from Brian Bercusson's analysis, which inspired the opinion of the European Economic and Social Committee of 14 November 1994, that only this interpretation would be consistent with the principle of autonomy of the social partners, which furthermore is based on the traditions and principles common to the Member States. The position of the European Economic and Social Committee is clearly that an obligation exists to propose a text. ${ }^{63}$

The interpretation according to which the Commission has an obligation to act is not an isolated opinion. It has been explicitly supported by a number of scholars. ${ }^{64}$

Some authors have insisted on a legality check, which could be carried out by the Commission, without ever suggesting that there is scope for a test on appropriateness. In our view, this statement comes close to that of the authors who put forward an obligation. ${ }^{65} \mathrm{~A}$ third group of authors has suggested that it is at the discretion of the Commission to push for or refuse tabling a proposal. ${ }^{66} \mathrm{In}$ a similar vein, other authors referring to the Commission's right of initiative seem either to reject the interpretation of this being an obligation, ${ }^{67}$ or explicitly ${ }^{68}$ or

\footnotetext{
${ }^{62}$ B. Bercusson, European Labour Law, 539.

${ }^{63}$ Opinion of the European Economic and Social Committee of 24 November 1994, SOC/275, para. 5.3.2.

${ }^{64}$ A. Jacobs, 'European social concertation' in Comisión Consultativa Nacional de Convenios Colectivos (ed), Collective bargaining in Europe (Madrid: Comisión Consultativa Nacional de Convenios Colectivos, 2005) 363; Ph. Watson, 'Social policy after Maastricht' (1993) 130 Common Market Law Review 481-513, specifically 507-508; E. A. Whiteford, 'Social policy after Maastricht' (1993) European Law Review $202 ;$ M. Weiss, 'Die Bedeutung von Maastricht für die EG-Sozialpolitik' in Däubler/Bobke/Kehrmann (eds), Arbeit und Recht, Festschrift Gnade (Bund Verlag Köln 1992) 593, M. Heinze, in Leinemann (Hrsg.), Kasseler Handbuch zum Arbeitsrecht (1997) § 11, para. 149; K. Riesenhuber, Europäisches Arbeitsrecht (Heidelberg (C. F.Müller) 2009) 120 ('Die Kommission soll dann vorbehaltlich einer Rechtmäßigkeitskontrolle zum Vorschlag verpflichtet sein.')

${ }^{65}$ U. M. Gassner in Vedder/Heintschel von Heinegg (eds), Europäisches Unionsrecht - Handkommentar (Nomos Baden-Baden 2012) AEUV Art. 155, para. 5; Schwarze in Oetker/Preis (eds.), Europäisches Arbeitsund Sozialrecht - EAS - Teil B Systematische Darstellungen - B 8100 (167. Aktualisierung März 2012, Forkel Verlag, Heidelberg) para. 72; Barnard, EC Employment Law (2nd edn (Oxford: Oxford University Press, 2000) 93 .

${ }^{66}$ Coen in Lenz/Borchardt, EU-Verträge - Kommentar (6th edn 2012, Bundesanzeiger Verlag Köln) AEUV Art. 155, para. 4; C. Welz, The European Social Dialogue under Articles 139 and 139 of the EC Treaty (2003) 323.

${ }^{67}$ In this footnote the authors are highlighted as primary sources in order to make them more easily visible (and distinguish them from the (secondary sources) to which they refer: M. Beneke in Grabitz/Hilf (eds), Das Recht der Europäischen Union (Band II, EUV/AEUV, Beck Verlag München, März 2011) Rn. 7; H. Buchner, RdA (1993) 201; S. Krebber in Callies/Ruffert (eds.), EUV - AEUV - Kommentar (4th edn 2011, Beck Verlag München) AEUV Art. 155, para. 26; R. Rebhahn in Schwarze (ed), EU-Kommentar (3rd edn 2012, Nomos Verlag Baden-Baden) AEUV Art. 155, para. 6; P. Rodière, Droit social de l'Union européenne, 2nd edn (Paris: LGDJ, 2002) 124; O. Schulz, Maastricht und die Grundlagen einer Europäischen Sozialpolitik (Carl Heymanns Verlag Köln a.o. 1996) 112-113; A. Wisskirchen, 'Der Soziale Dialog in der Europäischen
} 
implicitly ${ }^{69}$ to recognise the Commission's power to assess not only the legality but also the appropriateness.

In trying to assess this description it is interesting to note that the greatest number of authors is to be found in the third group, denying an obligation. But it is very surprising that only a few of them justify their point of view by referring to legal arguments (besides occasional references to the function of the Commission, in particular its role as 'initiative' body for the legislative procedure). The thesis that the Commission cannot assess the appropriate character is shared by the first two groups.

What is essential, however, is the quality of the argument, not the number of persons on one side or another.

A considerable number of experts ${ }^{70}$ adopting the view that the Commission has a margin of appreciation to assess the appropriate character of EU intervention have based their opinion on the communications of the Commission. The question does arise, therefore, whether these statements have a doctrinal added value or, to put it another way, whether these colleagues have taken any position at all in the debate. They often just seem to describe what is taking place without engaging in a legal analysis as such of the Commission's practice. ${ }^{71}$ These communications have no legal authority and, in view of the lack of arguments as well as of an obvious conflict of interest, no persuasive authority.

A major obstacle against the thesis of the positive obligation is arguably the UEAPME case. In its judgment, the General Court expressed the view that while on the one side 'the Council is to act on a proposal from the Commission', on the other side 'the Commission ... determines whether it is appropriate to submit a proposal to that effect to the Council':

84 In that regard, the Court would point out that, while it is for the management and labour concerned, alone, to initiate and take charge of the negotiation stage, properly so called, of the procedure governed by Article 3(4) and Article 4 of the Agreement (see above, paragraphs 75 and 76 ), when they conclude an agreement whose implementation at Community level they jointly request by virtue of Article 4(2) thereof, the Council is to act on a proposal from the Commission. Accordingly, the management and labour concerned address their joint request to the Commission which thereupon resumes control of the procedure and determines

Gemeinschaft' in Die Arbeitsgerichtsbarkeit - Festschrift zum 100jährigen Bestehen des Deutschen Arbeitsgerichtsverbandes (Luchterhand Verlag Neuwied 1994) 672.

${ }^{68}$ E. Eichenhofer, in R. Streinz (ed), EUV/AEUV (2nd edn, Beck-Verlag München 2012) Art. 155 AEUV, paras. 18 and 19.

${ }^{69}$ W. Frenz, Handbuch Europarecht (Bd. 6 Institutionen und Politiken, Springer Verlag Heidelberg a.o. 2011) para. 3937.

${ }^{70}$ See inter alia: E. Franssen, Legal aspects of the European Social Dialogue (Antwerpen, Intersentia, 2002) 207-208; C. Welz, The European Social Dialogue under Articles 138 and 139 of the EC Treaty (Alphen aan den Rijn, Kluwer Law International, 2008) 322-323.

${ }^{71}$ An example is the approach of Lo Faro (see his PHD thesis quoted above) who analyses the practice of the Commission and is very critical without stating that such a practice is indeed a violation of the TEC provisions. The author is more focused on a semantic issue, id est the inappropriate use of the language of collective bargaining on a phenomenon that is according to him more related to a regulatory resource. 
whether it is appropriate to submit a proposal to that effect to the Council. ${ }^{72}$ [Emphases added.]

These two statements can only be reconciled if we admit the possiblity of a complete separation of the two stages:

- first stage: the Commission has the power to decide on appropriateness grounds whether or not it proposes a decision to the Council, and if it does so:

- second stage: the Council is bound by the Commission's proposal.

In our view, the authority of these observations of the CJEU needs to be seen as qualified by the context in which they were made. First, the question whether there was a duty for the Commission to make a proposal was not at all the issue. In fact, the Commission had adopted a proposal, which had been approved by the Council. Furthermore, the General Court's UEAPME judgment was adopted at a time when the CFREU had not been adopted, nor had any reference to the duty to respect and promote the role of social partners been enshrined in the Treaty.

\section{B. THE TRAVAUX PRÉPARATOIRES OF ARTICLE 155 TFEU}

The travaux préparatoires of Article 4 of the Agreement on Social Policy (originally part of the Maastricht Treaty, now Article 155 TFEU) are atypical. The drafting of this provision is primarily based on the first cross-industry European agreement concluded on 31 October 1991. ${ }^{73}$ This Agreement was a major contribution of the European social partners to the 'constitutional' debate which would amount to the conclusion of the Maastricht Treaty. The signatories (ETUC, UNICE and (EEP) stated in that agreement:

2. Those agreements concluded at the Community level may be realized either according to the procedures and practices appropriate to the social partners and to the Member States or in matters covered by Article 118, at the joint request of the signatories, on the basis of a decision of the Council on a proposal from the Commission, with regard to the agreements as they have been concluded. This decision will follow the voting procedures of Article 118. [Emphasis added]

In the French wording of the agreement, the word 'peut' was used. This wording shows that the social partners did not intend to allow the Commission to have the power to amend the agreement, but it did provide some leeway to reject the joint request for institutional implementation.

Despite a joint declaration by the social partners on 3 July 1992 asking for this wording ('as they have been concluded') to be incorporated within the Agreement on Social Policy, opposition from the Member States - voting within the Council - prevented its inclusion in the text.

In his seminal work European Labour Law, Bercusson highlighted another major difference between the text of the social partners and the provisions

\footnotetext{
${ }^{72}$ General Court (previously Court of First Instance) 17 June 1998 - Case T-135/96 - UEAPME.

${ }^{73}$ See COM 93 (600) final:'Articles 3 and 4 reproduce in almost identical terms the agreement concluded'...
} 
fleshed out in the Agreement on Social Policy. While stating that 'the intention was clearly to make implementation of such agreements voluntary also as regards Member States or social partners within them, as well as in the case of action by the Community organs ${ }^{774}$, he argues that the Maastricht Treaty adopted a different stance. The path of voluntary implementation was abandoned and it was done so deliberately and intentionally by the Member States given the drafting the ASP. This stance is even more convincing when we consider the content of some drafts of the provisions which had been elaborated by the Dutch and Luxemburg Presidencies, which had both opted for an optional implementation. ${ }^{75}$

Given this major transformation in the drafting process, there can be no doubt that the Member States, in drafting the Agreement on Social Policy, wanted to reinforce the obligations of the European Commission, stressing the obligatory as opposed to the optional character of the implementation. ${ }^{76}$

The mere fact that the Member States did not reiterate the idea that neither the Commission nor the Council were entitled to change the text of the collective agreement in case of implementation is immaterial. First, this omission is not enough to prove that they could change the text. Secondly, the Commission in subsequent communications denied it had the right to amend the text of the agreements concluded.

\section{THE LEXICAL INTERPRETATION}

The interpretation based upon the travaux préparatoires is consistent with the outcome of a lexical (or literal) interpretation of Article 155 TFEU. Article 33(1) VCLT states that ' $[A]$ treaty shall be interpreted in good faith in accordance with the ordinary meaning to be given to the terms of the treaty'. Although going together, the words 'shall' and 'implement' contain two different aspects: the word 'shall' expresses the nature of the obligation whereas the word 'implement' describes its object.

As the first aspect, the word 'shall' will have to be analysed in more detail. In general terms this word is normally used in order to clarify that an obligation exists. A striking example can be found in the same provision, the last sentence of which reads: 'The European Parliament shall be informed.' Its obligatory character is not to be disputed. The sentence would (and indeed could) never be read as leaving any freedom of choice about whether or not to inform the Parliament.

To determine the level of obligation, the more imperative terms like 'must' or 'has/have to' also used in the Treaties should perhaps be taken into account.

\footnotetext{
${ }^{74}$ See also J. Degimbe, La politique sociale européenne (Brussels : ETUI, 1999, 230): 'Les partenaires sociaux ne voulaient accorder aucune marge de manœuvre au Conseil ne lui donnant d'autre choix que d'accepter ou de rejeter tels quels les accords conclus'.

${ }^{75}$ Heinze, in Leinemann (ed.), Kasseler Handbuch zum Arbeitsrecht, 1997, § 11, para. 149.

${ }^{76}$ B. Bercusson, European Labour law (1996) 542-543.
} 
On the other hand, there are many terms which do not include the word 'shall' but indicate what is supposed to happen in the present form (like 'The Union recognises and promotes the role of the social partners' in Article 152(1) TFEU), therefore also stipulating an obligation as mandatory, but in a less 'solemn' way.

As in Article 155(2)(1) TFEU, the words 'shall be implemented' are to be found in several provisions in the Treaties and it would appear that there is no real dispute about whether legal obligations derive from these provisions. ${ }^{77}$ The similar term 'shall implement' is also used in very different policy areas: Article 151(2) TFEU (Social Policy), Article 166(1) TFEU (Education, Vocational Training, Youth and Sport), Article 171(1) $2^{\text {nd }}$ indent TFEU (Trans-European Networks), Article 200(2) TFEU (The Union's Relations with International Organisations and Third Countries and Union Delegations), Article 317(1) TFEU (Financial Provisions).

Such a mandatory character is also intended in the TEU. The same word is used in Article 6(2) TEU concerning the obligation to adhere to the ECHR. Moreover, a comparison with four other linguistic versions (FR, DE, ES, IT) does not reveal any element which could be used to deny its obligatory character. Bercusson admitted that the French language version of the ASP was less conclusive than the English version, highlighting that in the French version which was submitted for signature, the wording 'la mise en oeuvre interviendra' was substituted by 'Ia mise en oeuvre intervient'. In our view, and contrary to Bercusson's doubts, the choice of the present tense (in French, the indicatif) ${ }^{78}$ only reinforces the obligatory and in fact legal character of the provision. It is rather the use of the future tense (in French, the future simple) which could raise some doubt about the legal character of the provision. In sum, in an English legal text, the imperative character of 'shall' should be rendered into French by the use of the present tense (indicatif) rather than of the future tense.

It is well known that an interpretation which would make the inclusion of a provision entirely pointless, meaningless or redundant can be rejected on the grounds of being absurd. The Vienna Convention contains an explicit admonition against interpretations which might be absurd or unreasonable (Article 32 VCLT). The interpretation of Article 155 TFEU as heralding an opposite view (optional), that is, that there is no obligation upon the European Commission to table a legislative proposal, makes Article 155 TFEU redundant. The opposite interpretation basically states that the European Commission can table legislative proposals based upon the content of the concluded agreements, provided that the substance of these agreements falls within the realm of matters covered by Article 153 TFEU. In our view, Article 153 TFEU already empowers the European Commission to table such proposals. There is no legal necessity to suggest that the Commission can table proposals which are 'inspired' by the existence of previously concluded agreements.

\footnotetext{
77 See Article 22 TEU(1)(3) TEU, Article 182(3) TFEU, Article 214(3) TFEU, Article 310(5) TFEU.

${ }^{78}$ See on the use of the 'indicatif' M. Schmitt, Autonomie collective des partenaires sociaux et principe de subsidiarité dans l'ordre juridique communautaire (Presses Universitaires d'Aix-Marseille, 2009) 260.
} 


\section{A TELEOLOGICAL, SYSTEMATIC AND CONTEXTUAL INTERPRETATION}

Article 31 VCLT does not construe a teleological, systematic and contextual interpretation as a simply a supplementary device to be used in case where a purely lexical interpretation does not allow provide a clear answer. Rather, it urges the interpreter Member States to take into account 'the ordinary meaning to be given to the terms of the Treaty in their context and in the light of its object and purpose.' [Emphasis added.]

An interpretation of an isolated provision which takes into account the context, object and purpose of an instrument, boils down to an interpretation which can be described as a teleological, contextual and systematic interpretation. Such an interpretation should try to consider the objectives and aims of Article 155 TFEU. Such an exercise means that the isolated provision under scrutiny needs to be contextualised within the Title on Social Policy. Furthermore, it means that the TFEU needs to be interpreted in the light of the Charter of Fundamental Rights of the European Union.

The most important element to consider here is Article 152 TFEU obliging the Union (and via Art. 13 TEU its institutions) to 'promote[s] the role of the social partners'.

The context of Article 155 TFEU is defined by the relevant provisions in the 'Social Policy' Title X of Part Three of the TFEU. This article is most closely related to the previous Article 154 TFEU but, more generally, to all the preceding Articles in the 'Social Policy' Title.

In the past, the CJEU provided evidence of such a systematic approach in a landmark case concerning the right to collective bargaining. In Albany the CJEU interpreted the scope of the competition provisions of the TFEU in the light of the relevant Articles of the Social Policy title related to the social dialogue. The CJEU interpreted the provisions dealing with the promotion of social dialogue at EU level as a shield to protect collective bargaining taking place at national level from the effects of negative integration through competition law.

This systematic interpretation is relevant here since it suggests that provisions in Policy Titles cannot be interpreted in an isolated way. This approach is consistent with the constitutional principle of coherence of the divergent policies in Article 7 TFEU. Furthermore, it highlights the point that such a systematic interpretation is not per se detrimental to social objectives but is capable of restricting the applicability of constitutional provisions of EU economic law. Hence, a systematic interpretation of isolated provisions within one Policy Title seems to be required here.

As highlighted in the previous sections, Article 155 TFEU needs to be related to the recognition of the right to collective bargaining in the CFREU. The question of whether this is a principle or a right or whether some of these provisions have a direct effect is not relevant in this context. Article 51(1) CFREU establishes an obligation on the European institutions not just to respect, but to promote the application of these rights. This obligation is of particular relevance. 
Article 151(1) TFEU indicates that the social dialogue is an objective of the Union as well as the Member States. It is not mentioned as a means of achieving other social objectives, but as an objective in its own right. In KHS AG/Winfried Schulte, AG Trstenjak summed up its relevance for interpreta-tion purposes:

the regulatory activity of the EU legislature pursuant to Article 137(1) EC [now Article 152(1) TFEU] is intended to contribute to achieving the objectives listed in Article 136 EC [now Article 153 TFEU]. Admittedly, this provision of the Treaty is in the nature of a programme, but this does not mean that it is devoid of any legal effect. It is acknowledged to be of essential importance for the interpretation of other provisions of the Treaty and of secondary Community legislation in social matters. $(29)^{79}$

This reference to the social dialogue as an objective is mirrored by Article 152 TFEU. This Article refers to an obligation to recognise and promote the role of social partners. The impetus on an obligation to respect and promote warrants the idea that the reference to 'autonomy' in Article 152 TFEU needs to be interpreted as the source of positive as well as negative obligations. In fact, Article 152 TFEU imposes an obligation to facilitate the dialogue between social partners, which implies a positive intervention by the institutions of the European Union. Article 154(1) TFEU reiterates this oblige-tion in a more specific way. It focuses on the obligations placed upon the European Commission as a European institution and stresses its obligation to consult the social partners. This provision also reiterates in a more gene-ric way the obligation of the Commission to take any relevant measure to facilitate dialogue by ensuring balanced support for the parties. There is no reason to assume that this obligation does not extend to the period fol-lowing the conclusion of an agreement.

In sum, the context of Article 155(2) TFEU elucidates the idea that a lexical interpretation of this provision as establishing an obligation to submit a proposal is entirely consistent with the idea of social partner autonomy in its positive dimension. Such an interpretation is consistent with the idea that the right to collective bargaining has been promoted by the adoption of such a provision, despite the fact that Article 155(2) TFEU predates the adoption of the Charter. The issue is of a hermeneutic and logical rather than a chronological nature.

In our view, a teleological interpretation could also profit from a comparative labour law perspective. As highlighted by Brian Bercusson in his article on 'The conceptualization of European Labour Law', 'the evolution of the labour and social law of the EC has been influenced by the mature and maturing conceptualization of the national labour laws of the original Member States and

\footnotetext{
79 Conclusions $07 / 07 / 2011$ - C-214/10 - KHS; in footnote 29 she refers to the relevant jurisprudence and (German) literature: '29 - See the judgments in Joined Cases C-72/91 and C-73/91 Sloman Neptun [1993] ECR 1-887, paragraph 26, and Case 126/86 Giménez Zaera [1987] ECR 3697, paragraph 14. To this effect, see S. Krebber, EUV/EGV - Kommentar (edited by Christian Calliess and Matthias Ruffert), 3rd edn, Munich 2007, Article 136 EC, paragraphs 31 and 38, p. 1578 et seq., and R. Rebhahn, and M. Reiner, EU-Kommentar (edited by Jürgen Schwarze), 2nd edn, Article 136 EC, paragraph 6, p. 1328, who point out that the main purpose of Article $136 \mathrm{EC}$ is to assist in the interpretation of secondary law and other provisions of primary law.'
} 
of later adherents ${ }^{80}$ Therefore, the divergent legal frameworks for industrial relations do constitute an important element in an attempt to put Article 155 TFEU in a 'context' which obviously transcends the TFEU as an instrument.

It has become a classical topos to compare the procedure in Article 155 TFEU with an extension procedure of collective agreements which exists in some EU Member States. In this respect, some scholars have pointed out that the Belgian Law on collective agreements and joint committees of 5 December 1968 would have been a source of inspiration in the drafting of the Agreement on Social Policy. ${ }^{81}$ In Belgium and in many other Member States, public authorities endowed with a system to extend collective agree-ments have a discretionary power to have recourse to an extension or not.

The comparison between the extension and the 'implementation' mechanisms is unfortunate, however, for a number of reasons. First, an extension mechanism only extends the existing binding collective agreement within a given legal domestic order. The implementation mechanism in EU law does not extend a pre-existing binding effect. It guarantees and introduces a binding effect of the implemented agreement in the EU legal order. Therefore, a refusal to implement is much more prejudicial to collective autonomy than a refusal to extend an agreement. If an implementation is refused, the European Union completely refrains from offering any support to social partners. The agreement will have no binding effect at all in the EU legal order.

Secondly, the conditions under which an extension can be put into effect are essentially different. In many Member States, the ability of public authorities to extend an agreement is not dependent on a joint request of the signatory social partners. The mere fact that there is no joint request regarding a collective agreement could warrant a cautious attitude from governments which are reluctant to take a position in a conflict between 'management' and 'labour'. In the hairdressers' case, the situation is entirely different.

\section{CONCLUSION}

The refusal by the Commission to submit a proposal to the Council, despite an explicit request from the social partners after having concluded the Hairdressers Agreement, is unprecedented. The conclusion of this agreement was a sign of the growing autonomy and maturity of the European Social Dialogue. The combination of an autonomous genesis with a heteronomous implementation procedure (through a directive) was also unprecedented. The Commission's attitude is at odds with the emphasis that the Lisbon Treaty has laid upon the autonomy of the social partners, which entails positive obligations for the EU

\footnotetext{
${ }^{80}$ Bercusson 595. 'Labour Law and Social Europe. Selected writings of Brian Bercusson' in N. Bruun, K. Lörcher and I. Schömann (eds). (Brussels: ETUI, 2009) 595.

${ }^{81}$ D. Dumont, 'Le dialogue social européen et ses instruments' in I. Hachez et autres (eds), Les sources du droit revisitées, (Anthémis, Limal, 2012) 337; J. Degimbe, La politique sociale européenne (Brussels, ETUI, 1999) 33.
} 
institutions, and it violates Article 155(2) TFEU. It is also inconsistent with the idea that the Charter of Fundamental Rights of the European Union obliges EU institutions to promote the rights enshrined in the Charter, including the right to collective bargaining. It represents a major shift from how the Commission has traditionally construed its role in assessing agreements submitted for implementation. No discourse on Better Regulation or Refit is able to justify this shift of attitude, insofar as collective agreements concluded between representative social partners have always been seen as examples of governance and better regulation by the actors involved long before this newspeak became trendy. This conclusion is relevant for agreements which have emerged as part of a more or less spontaneous order, outside the shadow of an intention of the Commission to legislate as well as for induced bargaining, irrespective of its sectoral or intersectoral nature.

One might argue that the attitude of the European Commission is the consequence of the autonomous genesis of the agreement, which was not induced by the European Commission, no invitation having been extended to the representative European social partners to give an opinion on this issue. However, in our view, nothing in Article 155 TFEU suggests that an obligation to propose a decision to the Council would only exist where the Commission has consulted the social partners. In fact, the first paragraph of Article 155 goes back to the Single European Act (1987), whereas the substance of Article 154 TFEU is rooted in the Agreement on Social Policy of the Maastricht Treaty (1992). The text of the latter was based upon an agreement of the European social partners. The duty of consultation is not even mentioned in Article 155 TFEU. Finally, the obligation to table a propo-sal after a joint request by the signatory parties does not presuppose that the agreement is concluded after a first or even second consultation, as happened in the aforementioned EPSU case. 